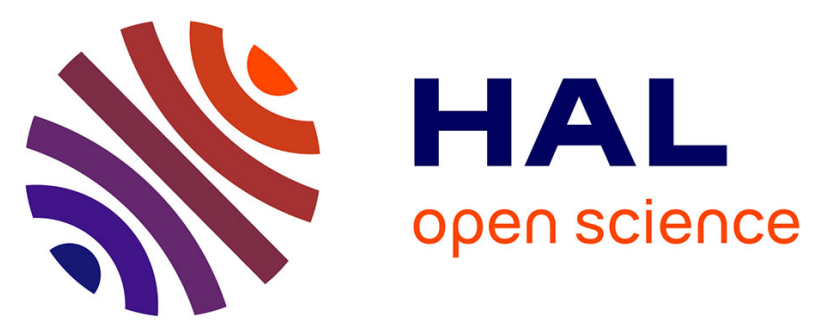

\title{
Comparison Between Polyurethanes Containing Castor Oil (Soft Segment) and Cancellous Bone Autograft in the Treatment of Segmental Bone Defect Induced in Rabbits
}

Oduvaldo Câmara Marques Pereira-Júnior, Sheila Canevese Rahal, Paulo

Iamaguti, Sérgio Luis Felisbino, Priscila Teodoro Pavan, Luiz Carlos Vulcano

\section{To cite this version:}

Oduvaldo Câmara Marques Pereira-Júnior, Sheila Canevese Rahal, Paulo Iamaguti, Sérgio Luis Felisbino, Priscila Teodoro Pavan, et al.. Comparison Between Polyurethanes Containing Castor Oil (Soft Segment) and Cancellous Bone Autograft in the Treatment of Segmental Bone Defect Induced in Rabbits. Journal of Biomaterials Applications, 2007, 21 (3), pp.283-297. 10.1177/0885328206063526 . hal-00570773

\section{HAL Id: hal-00570773 https://hal.science/hal-00570773}

Submitted on 1 Mar 2011

HAL is a multi-disciplinary open access archive for the deposit and dissemination of scientific research documents, whether they are published or not. The documents may come from teaching and research institutions in France or abroad, or from public or private research centers.
L'archive ouverte pluridisciplinaire $\mathbf{H A L}$, est destinée au dépôt et à la diffusion de documents scientifiques de niveau recherche, publiés ou non, émanant des établissements d'enseignement et de recherche français ou étrangers, des laboratoires publics ou privés. 


\title{
Comparison Between Polyurethanes Containing Castor Oil (Soft Segment) and Cancellous Bone Autograft in the Treatment of Segmental Bone Defect Induced in Rabbits
}

\author{
OdUVAldo CÂMARA MARQUEs PEREIRA-JÚNIOR, ${ }^{1, *}$ \\ Sheila Canevese Rahal, ${ }^{1}$ Paulo Iamaguti, ${ }^{1}$ SÉrgio Luis Felisbino, ${ }^{3}$ \\ PRISCILA TEODORO PAVAN ${ }^{1}$ AND LUIZ CARLOS VUlCANO ${ }^{2}$ \\ ${ }^{1}$ Department of Veterinary Surgery and Anesthesiology, Faculty of Veterinary \\ Medicine and Animal Science, Sau Paulo University \\ Rubiãc Júnior, s/n - 18618-000 - Botucatu - SP - Brazil \\ ${ }^{2}$ Department of Animal Reproduction and Veterinary Radiology \\ Faculty of Veterinary Medicine and Animal Science Rubião Júnior \\ s/n - 18618-000 - Botucatu - SP - Brazil \\ ${ }^{3}$ Department of Morphology Institute of Bioscience Sao Paulo \\ State University - UNESP Rubião Júnior \\ s/n - 18618-000 - Botucatu - SP - Brazil
}

\begin{abstract}
The aim of this study is to compare polyurethanes containing castor oil (soft segment) in granular form compared to cancellous bone autograft applied to a segmental bone defect. Norfolk adult female rabbits - approximately 13 months of age with a mean body weight of $4.5 \mathrm{~kg}$ - are used. In both radial diaphyses, $1 \mathrm{~cm}$ osteoperiosteal segmental defects are created. The defect in the left radius is filled with the castor-oil-based polyurethane, and the right one, filled with cancellous bone autograft, collected from the left proximal humerus. The rabbits are euthanazed at $15,30,60$, and 120 days postsurgery ( 5 animals/ period), for histological analyses. By radiographic analyses, at these time points,
\end{abstract}

*Author to whom correspondence should be addressed. E-mail: odujunior@yahoo.com.br Figures 3 and 4 appear in color online: http://jba.sagepub.com 
the bone regeneration is more evident and accelerated in the bone defects treated with the cancellous bone autograft. At 120 days postsurgery, the segmental bone defects treated with the cancellous bone autograft are totally reconstituted and remodeled, while the bone defects treated with polyurethane polymer have bone formation of $79 \%$. Histological study shows that the polyurethane acts as a space filler, minimizing the local production of fibrous tissue. No granule degradation, resorption or any inflammatory reaction is detected. Thus, it is possible to conclude that the castor-oil-plant-based polyurethane - in the granule presentation - is biocompatible and osteointegrated, but does not show the same bone regeneration capacity as the cancellous bone autograft.

KEY WORDS: biomaterial, segmental bone defect, bone, polyurethane.

\section{INTRODUCTION}

R one grafts have been used in the healing of the bone defects B in veterinary orthopedic surgery for several decades [9]. A graft is a tissue that contains living cells and is transplanted to another site to repair a defect. An implant involves the transfer of nonviable material to a living system [18]. Thus, autogenous cancellous bone graft is the most effective bone regeneration stimulator. Despite this, its limitations include increased operative time, limited availability, and significant morbidity at donor site [22]. Considering the limitations and disadvantages of obtaining and using autogenous bone, many biomaterials have been developed and tested with the intention of producing bone-graft substitutes [2,22]. Synthetic bone-graft substitutes have numerous advantages over autografts and allografts including their unlimited supply, easy sterilization, and storage. However, the degree to which the substitute provides an osteoconductive structural framework or matrix for new bone ingrowth differs among implants [4].

In the search for a new material that could be used as a bone substitute, in 1984, the Analytic Chemistry and Polymer Technology Group from the Sao Carlos Engineer School, University of Sao Paulo, developed a polyurethane derived from castor oil plant (Ricinus communis) [11]. The castor oil contains about $89 \%$ triglycerides from the hydroxyl-oleic acid. Structurally, the castor oil is a polyester containing three molecules of the 12-hydroxy-oleic acid $(\mathrm{C} 18: 1, \mathrm{OH})$, and each one shows a hydroxyl group at carbon 12 [13]. The polyurethane is obtained starting from two basic components: a polyol and a pre-polymer (both obtained by modification of the castor oil plant, using special techniques of urethane activation). The pre-polymer supplies isocyanate groups (NCO), and the polyol hydroxyl $(\mathrm{OH})$ groups for urethane reaction. The pre-polymerization reaction is between 
a diisocyanate and a polyol, and the final polymerization is carried through a diol, a diamine or a polyol. In the final product, there are no free active sites $(\mathrm{OH}$ or $\mathrm{NCO})$ for future interactions with the tissue where it will be implanted. However, there is a previously calculated quantity of urethane chains, which attracts the organic calcium in the process of bone integration [3]. This polyurethane presents, as a property, the alternative of being synthesized as a pure polymer or of adding other products, such as calcium carbonate that improve its capacity to integrate with the osseous tissue [13]. The product can be applied polymerized or as a soft mass that can be manipulated and molded as necessary, either previously or at the moment of the surgery [3].

Experimental studies [11,23] have confirmed the polyurethane potential for some orthopedic procedures. Thus, the biomaterial developed by the Analytic Chemistry and Polymer Technology Group from the Sao Carlos Engineer School was approved by the US Food and Drug Administration (FDA) in 2003 [7]. Actually there are many commercial presentations of this biomaterial, some are produced by Biomecanica Industries and named BioOsteo ${ }^{\circledR}$, which provides several different applications, such as pre-molded blocks, cylinders, chips, plugs, and also a form of biomass. The BioOsteo ${ }^{\circledR}$ was approved by the Brazilian Health Agency (ANVISA) in 1999 for clinical use [3].

Due to the limited experiments using different forms of the castor-oil-plant-based polyurethane, and in order to propose another alternative in bone regeneration, the aim of the present study is to compare the polyurethanes containing castor oil (soft segment) and cancellous bone autograft in the healing of radial segmental bone defect in rabbits.

\section{MATERIALS AND METHODS}

\section{Biomaterial Employed}

BioOsteo, in granule presentation $(850 \mu \mathrm{m}$ of diameter), with pores of $1-2 \mu \mathrm{m}$, is a polyurethane containing castor oil (soft segment), associated to calcium carbonate (34.5\% concentrated) that is authorized for medical use by the Brazilian Health Agency - ANVISA (register number 10171110079). According to the manufacturer, BioOsteo is a bone substitutive biomaterial, indicated for neurosurgical repair, prostheses fixation, bone rebuilding, and as bone space filler at orthopedics surgery and dentistry. To be employed, the granules must be added to physiological saline $(\mathrm{NaCl} 0.9 \%)$, blood or cancellous bone. 


\section{Surgical Procedure}

The present study was according to the guidelines for the care and use of laboratory animals and was approved by the Ethical Committee from the Faculty of Veterinary Medicine and Animal Science, UNESP at Botucatu.

Twenty female, Norfolk adult rabbits, 13 months old and weighing an average of $4.5 \mathrm{~kg}$ were used. The animals were numbered from 1 to 20 and divided into four groups according to postoperative observation time points ( $\mathrm{G} 1=15$ days, G2 $=30$ days, G3 $=60$ days, G4 $=120$ days). Each rabbit was placed in an individual $60 \times 60 \times 60 \mathrm{~cm}$ cage clear on the ground, and received water and commercial chow diet ad libitum.

The animals were tranquilized with an intravenous mixture of acepromazine $\left(0.1 \mathrm{mg} \mathrm{kg}^{-1}\right)$ and butorphanol $\left(0.1 \mathrm{mg} \mathrm{kg}^{-1}\right)$ and $15 \mathrm{~min}$ later were anesthetized with an association of tiletamine-zolazepam $\left(10 \mathrm{mg} \mathrm{kg}{ }^{-1}\right)$ and xylazine $\left(0.5 \mathrm{mg} \mathrm{kg}^{-1}\right)$. The surgical areas of both forelimbs were clipped, prepared, and draped under sterile technique. Using a craniomedial approach, a $1 \mathrm{~cm}$ segmental defect was created in the middle third of the right radial diaphysis using a circular bone saw and high-volume irrigation with $0.9 \%$ saline solution. The osseous fragment was removed with the periosteum. The ulnar periosteum adjacent to the site of the defect was also removed. Autogenous cancellous bone collected from the left proximal humerus was implanted in the bone defect immediately after collection. The same surgical procedure was performed on the left forelimb although the bone defect was filled with polyurethane granules $(100 \mathrm{mg})$ homogenized with $0.1 \mathrm{~mL}$ of autologous blood. The soft tissue and skin incisions were closed with interrupted sutures using nylon 3-0.

Enrofloxacin $(5 \mathrm{mg} / \mathrm{kg} \mathrm{SC})$ was administered at the time of anesthesia induction and $24 \mathrm{~h}$ after surgery. Buprenorphine was administered $(0.02 \mathrm{mg} / \mathrm{kg} \mathrm{SC})$ every $12 \mathrm{~h}$ for 5 days. The surgical wounds were cleaned with saline and povidone-iodine, and skin sutures were removed 10 days after surgery.

Clinical evaluation consisted of observations of wound healing, weight bearing on both forelimbs, and other possible complications. Radiographic examinations in craniocaudal and lateral positions of both forearms were made immediately after surgery and at $15,30,60$, and 120 days postoperative. Radiographs were used to evaluate new bone formation within the bone defect. Total area of bone defect and areas of bone neoformation were traced on a transparent sheet at 30,60, and 120 days postoperative. The images were captured by XC77 Sony digital camera and the areas were measured using the KS-300 image analysis 
system (version 3.0). The percentage of bone neoformation was obtained by dividing the bone neoformation total area by the bone defect total area.

In order to complete the histological analyses, five animals were euthanized at $15,30,60$, and 120 days postsurgery by intravenous administration of an overdose $\left(15 \mathrm{mg} \mathrm{kg}^{-1}\right)$ of sodium pentobarbital followed by potassium chloride at $19.1 \%(1 \mathrm{~mL} / 3 \mathrm{~kg} \mathrm{IV})$. The histological specimens were collected and stored in $10 \%$ phosphate buffered formalin.

\section{Histology}

After 1 week of fixation in phosphate buffered formalin, followed by decalcification in a $10 \%$ buffered acetic acid solution, the decalcified specimens were dehydrated in ethanol and clarified in xylene. After dehydratation, the implant blocks were infiltrated and embedded in paraffin plus synthetic resin (HISTOSEC, Merck KgaA, Germany). Each block was sectioned parallel to the longitudinal axis of the radius on a Leica cutting machine. Semi-serial sections, $5 \mu \mathrm{m}$ thick, were obtained and stained with hematoxilin-eosin stain.

\section{Analysis of Results}

Using the stained histological sections, light microscopic histomorphometry was performed on a Leica DMLB microscope (Leica Corp., UK), connected to a Leica DC300FX color video camera and a Leica QWin Standard Version 3.1.0. image analysis software to determine the areas of the implanted material, new bone formation, and cartilaginous tissue.

After testing data for normality, the parametric Student's $t$-test was used to compare two experimental groups. Analysis of variance followed by performing the Tukey test to evaluate the four different time points, using the GraphPad InStat software. Differences were considered statistically significant at $p<0.05$.

\section{RESULTS}

The animals were fully mobile and started to bear weight on the forelimbs 1-2 days postsurgery. There were no signs of infection and all surgical wounds were in the process of healing.

The radiographs carried out immediately after surgery showed that the bone defects were standard and surfaces of the section were 

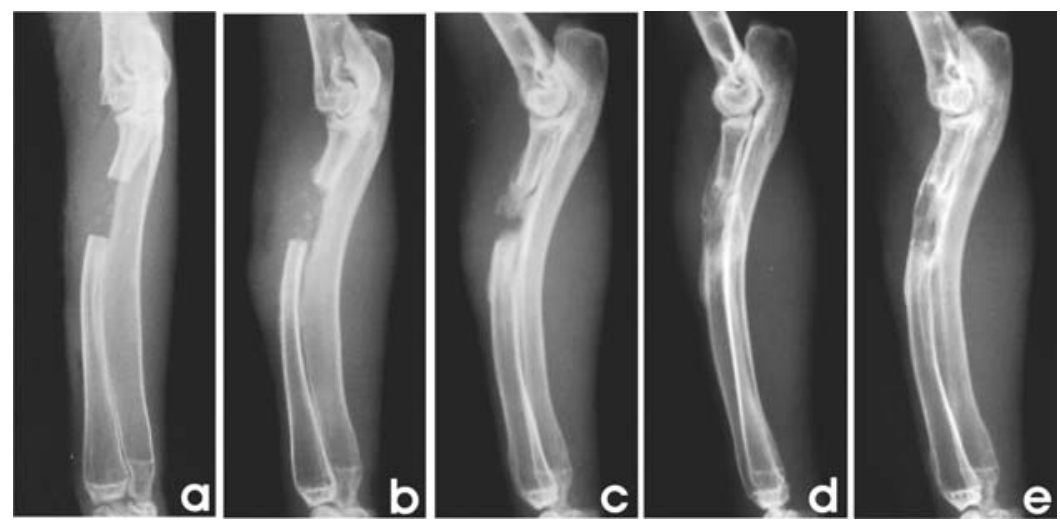

Figure 1. Lateral radiographs of the radius treated with cancellous bone autograft: (a) immediately after surgery and at; (b) 15; (c) 30; (d) 60; and (e) 120 days postoperative. The beginning of bone neoformation may be seen at the proximal radius cut edge and at the center of the defect on postsurgery day 15 (b), which occupies about $70 \%$ of the defect 30 days postsurgery (c). At 60 days postoperative, newly formed bone occupies $100 \%$ of the defect (d) and at 120 days postsurgery, bone remodeling is detected (e).

homogeneous in all limbs. There was no modification of the bone alignment. Immediately after surgery, the defects treated with cancellous bone autograft were also radiolucent. At 15 days after surgery, the beginning of bone formation could be observed, primarily developing from the radius cut bone ends and the ulnar side. Progressive bone formation was observed at the other time periods. The percentage of new bone formation within the bone defect was approximately of $77.8,85$, and 100 at 30,60 , and 120 days after surgery, respectively. Radiopacity similar to the contiguous bone was observed in $25 \%$ of the limbs at 120 days after surgery and there were signs of bone modeling. The presence of a radiolucent area in the center of the defect was seen in only one limb (Figure 1).

The defects treated with castor-oil-based polyurethane showed radiopacity immediately after surgery, due to the radiopacity of the biomaterial. At 15 days after surgery, the beginning of bone formation was noted, generally developing from the radius cut bone ends and the ulnar side. Progressive bone formation was observed at the other time points. The percentages of new bone formation within the bone defect were approximately 54,61.4, and $79 \%$ at 30,60 , and 120 days after surgery, respectively. At 120 days postsurgery, areas of radiotransparency were still observed in the central region of the defect in all animals (Figure 2). 

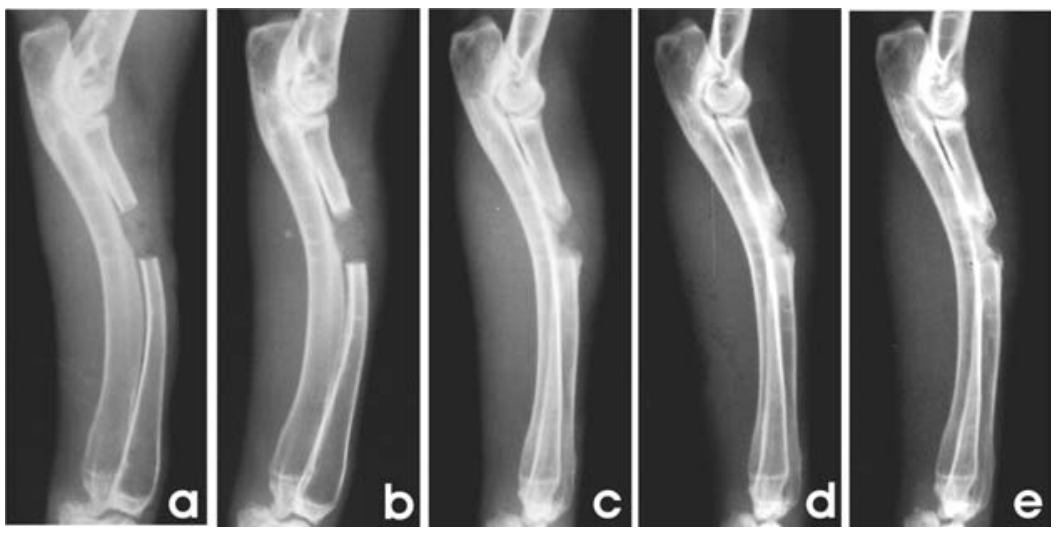

Figure 2. Lateral radiographs of the radius treated with polyurethane containing castor oil: (a) immediately after surgery and at; (b) 15; (c) 30; (d) 60; and (e) 120 days postoperative. New bone formation was observed from the cut edges of the radius and from the cranial face of the ulna that occupies about $60 \%$ of the bone defect on postoperative day 30 (c). At 60 days postsurgery (d), newly formed bone was observed occupying $79 \%$ of the defect. On postsurgery day 120 (e), there is no increase in percentage of bone neoformation, but there are signs of bone remodeling.

The histological evaluations of the defects treated with cancellous bone showed intense cartilaginous formation at 15 days postoperative. Trabecular bone neoformation areas originated from the cut bone ends of the radius and, specially, from the ulna surface. Connective tissue derived from the periosteum was present in the middle and cranial areas of the defect. The bone graft was not observed. At 30 days postsurgery, the cartilaginous tissue was decreased and its replacement by trabecular bone was observed. Bone neoformation was increased, filling almost all the defect area. Connective tissue was covering the cranial surface of the defect. At 60 days, the trabecular bone area was decreased compared to 30 days postoperative due to the bone modeling process and areas of bone marrow development. These areas were detected all over the segmental defect, but without a defined medullar canal. The bone cortex was still incomplete. At the final time point (120 days), cartilaginous tissue had been completely replaced by bone tissue, except in one animal. The bone marrow area was increased, forming a well-defined medullary canal. All animals showed bone cortical linking both edges of the radius (Figure 3(a)).

At 15 days postsurgery, the histological evaluations of the defects treated with castor-oil-plant-based polyurethane showed the presence of cartilaginous tissue and its replacement by primary bone. There was 


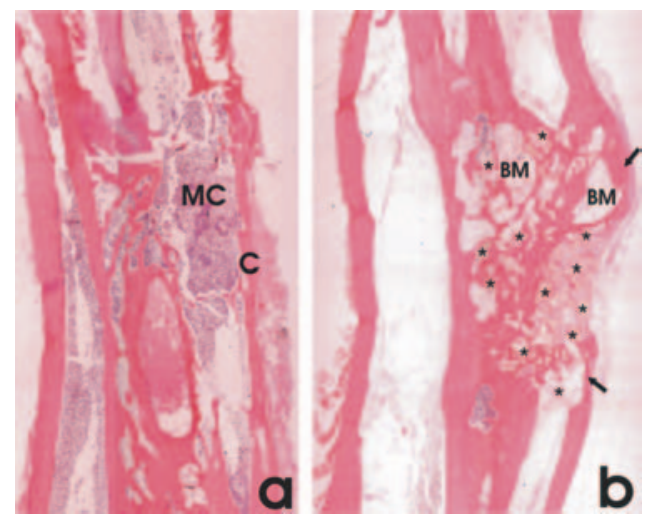

Figure 3. Comparison at 120 days postoperative between histological analyses of the radii treated with: (a) cancellous bone autograft and (b) polyurethane containing castor oil. The formation was observed of a fine cortical bone (C) and of the medullar canal (MC) in the region of the created bone defect (a). It was seen that at the defect treated with the polyurethane (b) there are zones of bone marrow (BM) without an evident medullar canal and granules of polyurethane (asterisk) surrounded by newly formed bone or by marrow bone. Bone cortical (arrows) is not complete in the defect treated with polyurethane.

new bone formation originated from the ulna and from the cut bone ends. Polyurethane granules were easily identified, although they were not stained by hematoxylin and eosin. They were agglomerated in the central area of the defect and the majority of them were surrounded by connective tissue. The most peripheral granules showed intimate contact or were totally surrounded by cartilaginous tissue and trabecular bone. No evidence of inflammatory reaction was detected, nor any multinucleate giant cells were found. At 30 days, new bone formation was increased, derived from the ulna and from the cut bone ends, and more granules of the polymer were surrounded by trabecular bone and cartilaginous tissue. The connective tissue surrounding the granules in the center of the defect was decreased. At 60 days postsurgery, no cartilaginous tissue was detected. Newly formed bone areas showed a reduction and were more compacted, especially next to the ulna surface. Marrow bone areas were visualized near the cut bone ends. Intimate contact among newly formed bone, marrow bone, and polyurethane granules was detected, with no evidence of intervening layers of fibrous tissue. At the last moment of evaluation (120 days), newly formed bone was increased and showed lamellar aspect. Bone marrow areas were present in a larger number and no evidence of granules degradation was detected. The granules were surrounded by newly formed bone, bone marrow, and also by connective tissue, 

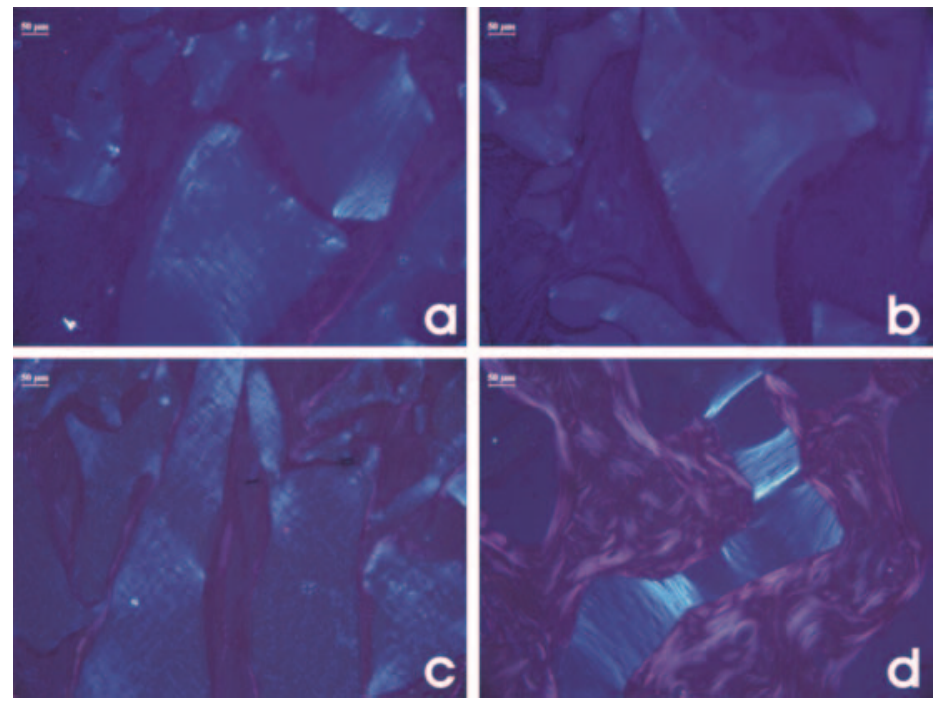

Figure 4. Polarized microscopy to observe the structural organization of the polyurethane granules. There is no evidence of granule structural organization alteration at: (a) 15; (b) 30; (c) 60; and (d) 120 days postoperative.

especially in the cranial area of the defect. Complete external cortical bone was not detected (Figure 3(b)). Polarization microscopy showed no alterations in the organization of standard structural granules among all the evaluation time points (Figure 4). Variance analysis of the mean areas of polymer granules in the segmental bone defect did not show any statistical difference (Table 1) among the four evaluation time points $(15,30,60$, and 120 days postsurgery).

The cancellous bone autograft-treated forelimbs did show more trabecular bone production than the polyurethane-treated forelimbs (Table 2). However, the histomorphometric analyses showed that only at 30 days postsurgery was a statistically significant difference $(p<0.05)$ detected when the new bone area was evaluated.

\section{DISCUSSION}

Castor-oil-based polyurethane was produced in granule form in order to simulate the intrinsic characteristics of the surgical form of cancellous bone such as manipulation and application, in contrast with other treatments that used it for pre-molded blocks $[6,12,17]$. Also, the addition of autogenous blood was important to enhance the aggregation of the granules, and avoid their dispersion in the recipient site. Although 
Table 1. Average values $\left(\mathrm{mm}^{2}\right)$ of the polyurethane granules areas present in the bone defect at all evaluation time points.

\begin{tabular}{ccccc}
\hline & \multicolumn{4}{c}{ Evaluation time points (postoperative days) } \\
\cline { 2 - 5 } & 15 & 30 & 60 & 120 \\
\hline Area & $9.207 \pm 1.42$ & $9.684 \pm 0.64$ & $7.909 \pm 1.42$ & $9.470 \pm 2.39$ \\
\hline
\end{tabular}

There was no significant difference among the time points ( $p>0.05$ ANOVA).

Table 2. Comparison among the average values $\left(\mathrm{mm}^{2}\right)$ of newly formed bone in the bone defect as a function of the treatment (cancellous bone autograft or polyurethane containing castor oil) and time.

\begin{tabular}{lcccc}
\hline & \multicolumn{4}{c}{ Evaluation time points (postoperative days) } \\
\cline { 2 - 5 } Treatment & 15 & 30 & 60 & 120 \\
\hline Autograft & $8.156 \pm 5.12$ & $25.741 \pm 7.70$ & $15.790 \pm 2.45$ & $14.063 \pm 3.50$ \\
Polyurethane & $11.019 \pm 6.52$ & $13.582 \pm 8.66^{\star}$ & $12.133 \pm 3.78$ & $17.394 \pm 4.46$ \\
\hline
\end{tabular}

${ }^{*} p<0.05$ by Student's t-test related to the respective pair, at the same moment of evaluation.

no barrier had been used, such as osteopromotive membranes [27], the biomaterial remained concentrated in the bone defect, as observed by radiographic and histological evaluations.

The radiographic examination was not sufficient to evaluate the polyurethane granules due to their low radiopacity, despite another study suggesting conventional radiography as an excellent method to evaluate the bone tissue biological behavior using the castor-oilbased polyurethane [25]. Calcium carbonate is responsible for polyurethane's radiopacity, and generally it is present at concentrations of $34-40 \%$ [3,6]. Calcium carbonate may improve the polymer osteointegration [13]. Also, no biocompatibility difference was shown when polyurethane discs, supplemented or not with calcium carbonate, were implanted into subcutaneous tissue of mice [19].

Bone regeneration was more evident and accelerated in the bone defects treated with cancellous bone autograft more than those treated with castor-oil-based polyurethane at all time points, as measured by radiographic analyses. At 120 days postsurgery, the segmental bone defects treated with cancellous bone autograft were totally reconstituted and modeled, while the bone defects treated with polyurethane polymer had $79 \%$ bone formation. As reported by other authors, the cancellous bone autograft is still the best bone regeneration stimulator [14,22]. 
Histological examination findings helped to interpret and confirm the radiographic findings. Trabecular bone area was statistically greater in defects treated with autograft cancellous bone than in the ones treated with polyurethane polymer only at 30 days postsurgery. No difference was seen at 60 or 120 days postoperative because of diminution of trabecular bone area caused by acceleration of reabsorbing and modeling processes that occurred in the defects treated with autograft cancellous bone. Also, at 120 days postsurgery the medullar canal was completely reconstituted in this group, compared to the polyurethane-treated group, in which no medullar canal was observed. Similar results were observed after inducing a bone defect in calvaria of rabbits treated with castor-oil-based polyurethane which showed no inflammatory reaction and partial bone formation. However, the defects treated with autograft were filled by newly formed bone and showed evidence of the modeling process 40 days after surgery [24].

Histological analysis at 15 days postsurgery did not show the cancellous bone autograft, but there was a presence of cartilaginous tissue and areas of trabecular bone neoformation. In general, a majority of cancellous autograft cells die due to ischemia or induction of apoptosis after transplant to the receptor site; however, the most resistant cells, the primitive mesenchymal cells and progenitors of endothelial cells, proliferate and stimulate bone production [1].

In the present study, no evidence of inflammatory reaction or giant foreign body cells was observed by histological analysis at any time point, suggesting the biocompatibility of the polyurethane polymer. The same results were observed by other authors after using other presentations of castor-oil-based polyurethane implanted in circular defects induced in the rabbit medial condyle [23], rabbit calvarium [24], rat mandible [26], and rat tibia [20], as well as in segmental defects induced in the rabbit radius [11] and rat zygomatic arc [15]. Even though giant foreign body cells have been observed when polyurethane was implanted in the rat dental alveolus [5], the authors did not consider it as a sign of incompatibility due to the infrequent occurrence.

Polyurethane granules became concentrated in the center of the bone defect and were progressively surrounded by the trabecular bone in the way that the bone proliferation developed from the ulna and both edges of the radius. At the final evaluation time point, some granules were still surrounded by connective tissue. These results suggest that this biomaterial may be able to cause osteointegration, which was characterized by direct anchorage of an implant due to the bone formation around it, but without proliferation of fibrous tissue in the bone-implant interface [21]. In addition, the osteointegration capacity of 
this biomaterial, as irregular flakes (from 700 to $1200 \mu \mathrm{m}$ of diameter), when implanted in the dental alveolus of rats was shown [5]. In the same way, an intimate contact between the polyurethane granules and trabecular newly formed bone was detected in the present study at all evaluation time points, confirming the osteointegration potential of castor-oil-based polyurethane. However, when the polyurethane was applied into the bones of dogs as porous or compact cylinder [13], pin [17], or bone cement [28] the biomaterial was not considered osteointegrated because of the development of fibrous capsule around the implants.

An osteoconductive material promotes bone apposition to its surface, acting as a receptive scaffold that facilitates enhanced bone formation [2] through the incursion of blood vessels and newly formed bone to its scaffold [10]. In this study, newly formed bone was detected on the surface of the polymer granules, however not inside its scaffold. Thus, considering that the biomaterial used in the present study presents pores of $1-2 \mu \mathrm{m}$ diameter [3], it was not possible to observe the same osteoconductive potential. In vitro studies showed that $20 \mu \mathrm{m}$ is the minimum pore size that facilitates cellular penetration, but pore size larger than $50 \mu \mathrm{m}$ is necessary to benefit new bone formation inside it [16]. To obtain the osteoconductive ability, it would be necessary to increase the porosity of the biomaterial used in the present experiment. However, osteoconductive ability was observed when the castor-oil-based polyurethane was used as blocks, cylinders, or as flakes $[6,8,11,15,23]$.

No sign of polymer resorption was detected by histological examination, and statistically the mean occupation area of the granules was the same at all time points. Moreover, polarization microscopy did not show any difference in structural organization of the granules, suggesting that the polyurethane polymer may be used as a space filler. In the same way, no resorption or substitution of the polyurethane polymer implanted intraosseously as cylinders in rabbit condyle was observed in histological studies [23]. When compact or porous polyurethane polymers were used in circular bone defect induced in dog femoral condyle, radiographic and tomographic studies, and scanning electronic microscopy did not detect the cut surface irregularities indicative of degradation [13]. Minimum resorption of polyurethane by cellular action was described, when it was injected into a $1 \mathrm{~mm}$ defect induced in the tibia of rats [20]. On the other hand, resorption and substitution of the castor-oil-based polyurethane was found when blocks were implanted in $2 \mathrm{~mm}$ segmental defects created in the zygomatic arch of rats [15]. 
According to the conditions under which the present study was performed and based on the results obtained, it was possible to conclude that the polyurethane containing castor oil (soft segment) in granule presentation does not have osteoinductive and osteogenic properties of the cancellous bone autograft. By histological analyses, the polymer granules acted as a space filler, diminishing the production of a connective tissue in the bone defect, with no sign of degradation. Moreover, it is biocompatible and osteointegrated.

\section{ACKNOWLEDGMENTS}

The authors are grateful to Eduardo Hatschbach, for the help in the anesthetic procedure; Alexandre L.C. Bicudo, for the help in the radiographic procedure; and Capes, for financial support.

This work constituted a part of the MSc Thesis presented to Universidade Estadual Paulista-UNESP, in 2005, by Oduvaldo C.M. Pereira-Júnior.

\section{REFERENCES}

1. Bauer, T.W. and Muschler, G.F. (2000). Bone Graft Materials: An Overview of the Basic Science, Clin. Orthop. Relat. Res., 1(371): 10-27.

2. Bauer, T.W. and Smith, S.T. (2002). Bioactive Materials in Orthopaedic Surgery: Overview and Regulatory Considerations, Clin. Orthop. Relat. Res., 395: $11-22$.

3. Bioosteo. Bioosteo. (2004). Available from: <http://www.biomecanica. com.br> [cited 2004 Apr 10].

4. Bucholz, R.W. (2002). Nonallograft Osteoconductive Bone Graft Substitutes, Clin. Orthop. Relat. Res., 395: 44-52.

5. Calixto, R.F.E., Teófilo, J.M., Brentegani, L.G. and Carvalho, T.LL. (2001). Implantation of Flakes of Castor Oil Resin in Rat Dental Alveolus, Pesqui. Odontol. Bras., 15(3): 257-262.

6. Del Carlo, R.J., Kawata, D., Viloria, M.I.V., Oliveira, D.R., Silva, A.S., Marchesi, D.R., Galvão, S.R., Azevedo, P. and Monteiro, B.S. (2003). Castor Oil Plant Polymer and Calcium Associated or not to Autogenous Bone Marrow in Bone Gaps Repair, Ciênc. Rural, 33(6): 1081-1088.

7. Ereno, D. (2003). Engenharia de materiais - próteses de mamona, Pesqui. Fapesp, 91: 66-71.

8. Figueiredo, A.S., Fagundes, D.J., Novo, N.F., Inouye, C.M., Takita, L.C. and Sassioto, M.C.P. (2004). Devitalized Bovine Bone, Porous Coralline Hydroxyapatite, Castor Beans Polyurethane and Autograft Implants in Rabbits, Acta Cir. Bras., 19(4), Available from <http://www.scielo.br/acb>. [cited 2005 Jun 16]. 
9. Fitch, R., Kerwin, S., Sinibaldi, K.R. and Newman-Gage, H. (1997). Bone Autografts and Allografts in Dogs, Compend. Contin. Educ. Pract. Vet., 19(5): 558-578.

10. Greenwald, A., Boden, S.D., Goldberg, V.M., Khan, Y., Laurencin, C.T. and Rosier, R.N. (2001). Bone-graft Substitutes: Facts, Fictions, and Applications, Bone Joint Surg. Am., 83(suppl.): 98S-103S.

11. Ignácio, H. Utilização do cimento derivado do polímero da mamona no preenchimento de falha óssea, Estudo experimental em coelhos.

12. Ignácio, H., Mazzer, N., Barbieri, C.H. and Chierici, G. (1996). Estudos sobre a aplicabilidade médica da poliuretana derivada da mamona, Res. Ortop., 2(6): 10-12.

13. Ignácio, H. (1999). Avaliação da poliuretana da mamona nas formas compacta e porosa no preenchimento da falha óssea. Estudo experimental em cães. [tese]. Ribeirão Preto: Faculdade de Medicina, Universidade de São Paulo.

14. Lane, J.M., Tomin, E.B.S. and Bostrom, M.P.G. (1999). Biosynthetic Bone Grafting, Clin. Orthop. Relat. Res., 367(suppl.): 107S-117S.

15. Leonel, E.C.F., Andrade Sobrinho, J., Ramalho, Oliveira, L.T., Porciúna, H.F. and Mangilli, R. (2004). The Action of the Castor Bean Polymer During the Bone Neoformation, Acta Cir. Bras., 19(4): 342-350.

16. Lu, J.X., Flautre, B., Anselme, K., Hardouin, P., Gallur, A., Descamps, M. and Thierry, B. (1999). Role of Interconnections in Porous Bioceramics on Bone Recolonization in vitro and in vivo, J. Mater. Sci. Mater. Med., 10(2): 111-120.

17. Maria, P.P., Filho, Padilha, J.G. and Castro, M.B. (2003). Macroscopic and Histopathologic Evaluations of the use of Polyurethane Resin Derived from Castor Oil (Ricinus communis) Applied in the Tibia of the Puppies, Acta Cir. Bras., 18(4): 332-336.

18. Martinez, S.A. and Walker, T. (1999). Bone Grafts, Vet. Clin. Nor. Am.: Small An. Pract., 29(5): 1207-1219.

19. Mastrantonio, S.D.S. and Ramalho, L.T.O. (2003). Mouse Connective Tissue Reaction to Polyurethane Derived from Castor Oil, Rev. Odontol. UNESP, 32(1): 31-37.

20. Mendoza-Barrera, C., Meléndez-Lira, M., García-López, E. and HernándezFlores, C. (2004). Caracterización estructural y biointegración del substituto óseo BioOsteo ${ }^{\circledR}$, Rev. Mex. Fís., 50(1): 19-23.

21. Merck (2005). Merck Source - Health Information, Osseointegration. Available from: <http://www.mercksource.com/pp/us/cns/cns_home.jsp > . [cited 2005 Jul 25].

22. Moore, W.R., Graves, S.E. and Bain, G.I. (2001). Synthetic Bone Graft Substitutes, Anz. J. Surg., 71(6): 354-361.

23. Ohara, G.H., Kojima, K.E., Rossi, J.C., Telles, M., Soares, T.V.C., Salomão, C. and Sanda, M. (1995). Experimental Study of the Biocompatibility of Castor Bean's Polyurethane Resin Intraosseous and Intraarticularly Implanted in Rabbits, Acta Ortop. Bras., 3(2): 62-68.

24. Oliveira, M.F., Ueda, J.K., Resende, D. and Filho, Scarso, J. (1995). Estudo comparativo entre a reparação de um biomaterial baseado em poliuretana 
derivado do óleo de mamona e do osso autógeno implantados em sítios realizados na calvária de coelhos. Análise histológica, In: Proceedings of the 9th Araraquara Academic Journey - UNESP, Araraquara: Sao Paulo, Nov $14-15$, p. 74.

25. Silva, M.J.A., Tavano, O., Guimarães, S.A.C. and Gomes, M.F. (1997). Bone Radiographic Study Associated to a Castor Bean Polyurethane Resin in Surgical Defects in Rabbits: Radiopacities Quantitative Analysis, Rev. FOB., 5(3/4): 69-77.

26. Teixeira, H.M. and Ramalho, L.T.O. (1995). Reação a resina vegetal de mamona durante o processo de reparo em defeitos ósseos induzidos no corpo da mandíbula, In: Proceedings of the 9th Araraquara Academic Journey UNESP, Araraquara: Sao Paulo, Nov 14-15, p. 117.

27. Zellin, G. and Linde, A. (1996). Effects of Different Osteopromotive Membrane Porosities on Experimental Bone Neogenesis in Rats, Biomaterials, 17(7): 695-702.

28. Ziliotto, L., Fantinatti, A.P., Daleck, C.R., Filho, Padilha, J.G., Souza, A.P. and Diniz, P.P.V.P. (2003). A Limb Sparing Surgery with the use of a Cortical Allograft Preserved in Glicerin: An Experimental Study in Dogs, Acta Cir. Bras., 18(2): 107-115. 